\title{
ISRM Suggested Methods for Rock Stress Estimation-Part 5: Establishing a Model for the In Situ Stress at a Given Site
}

\author{
Ove Stephansson $\cdot$ Arno Zang
}

Published online: 23 June 2012

(C) Springer-Verlag 2012

\section{Introduction}

This contribution relates to the updated suggested method for rock stress estimation and concerns the final rock stress model (FRSM) of a site or an area. The previous four suggested methods are (1) Part 1: strategy for rock stress estimation (Hudson et al. 2003), (2) Part 2: overcoring methods (Sjöberg et al. 2003), (3) Part 3: hydraulic fracturing (HF) and/or hydraulic testing of pre-existing fractures (HTPF) (Haimson and Cornet 2003), and (4) Part 4: quality control of rock stress estimation (Christiansson and Hudson 2003).

The aim of a site or an area characterization for underground works is to produce a three-dimensional model containing information about topography, soils, rock mass lithology, structural geology, hydrogeology and mechanical data, including rock stress. Such a geological model is needed in analyzing the cause and effect on stresses from lithology boundaries, geological structures, faults and fracture zones intersecting the site or area. Although it is impossible to know all the details of the geological evolution of a site or an area, it is worth the effort of trying to ascertain the in situ stress state from the bulk knowledge of the site morphology, topography

Please send any written comments on this ISRM Suggested Method to Prof. Resat Ulusay, President of the ISRM Commission on Testing Methods, Hecettepe University, Department of Geological Engineering, 06800 Beytepe, Ankara, Turkey.

O. Stephansson · A. Zang $(\bowtie)$

Department 2: Physics of the Earth, Sect. 2.6: Seismic Hazard and Stress Field, GFZ German Research Centre for Geosciences, Telegrafenberg, 14473 Potsdam, Germany

e-mail: zang@gfz-potsdam.de and geology, and if possible, to verify this information with additional data from boreholes and drill cores. We advocate that stress measurements to be conducted after the best estimate stress model (BESM) has been compiled. Sometimes numerical models can be of assistance in estimating the effect of geological parameter variations in the establishment of a stress model for a site. In this contribution, a strategy and flow chart is presented to establish the FRSM from a combination of available stress data from the BESM, new stress data from stress measurement methods on site (SMM) and integrated stress determination (ISD) using previous data plus numerical modeling (see Fig. 1). We are aware that sometimes the economic constraints prevent application of all the steps in establishing the FRSM. However, the goal of a stress measurement campaign is to collate and harmonize the data in the best way to describe the in situ stress condition of a site or area.

\section{Overview of the Final Rock Stress Model (FRSM)}

In situ stress exists in a rock mass prior to any manmade disturbances. Figure 1 presents the way forward for deriving the FRSM for a site or an area (Zang and Stephansson 2010). The BESM is established by collecting existing information from databases and analyzing field data on morphology, topography, geology, borehole and drill core information. Before any in situ stress measurements, the development of the BESM of the site or area is recommended. The established stress model should be used in selecting the appropriate stress measurement technique and assist in planning the measurements. After the BESM is established and stress measurement conducted, an integrated stress determination (ISD) should follow. In this last 
Fig. 1 Generation of the final rock stress model (FRSM) by combination of the best estimate stress model (BESM), new stress data from stress measurement methods (SMM) and integrated stress determination (ISD), after Zang and Stephansson (2010)

\begin{tabular}{|c|c|c|c|c|}
\hline \multicolumn{2}{|c|}{$\begin{array}{l}\text { Best Estimate } \\
\text { Stress Model } \\
\text { BESM }\end{array}$} & $\begin{array}{l}\text { Stress } \\
\text { Measurement } \\
\text { Methods } \\
\text { SMM }\end{array}$ & $\begin{array}{l}\text { Integrated } \\
\text { Stress } \\
\text { Determination } \\
\text { ISD }\end{array}$ & $\begin{array}{l}\text { Final Rock } \\
\text { Stress Model } \\
\text { FRSM }\end{array}$ \\
\hline 离 & $\begin{array}{l}\text { Estimation of } \\
\text { classes of stress } \\
\text { World Stress Map } \\
\text { Database }\end{array}$ & 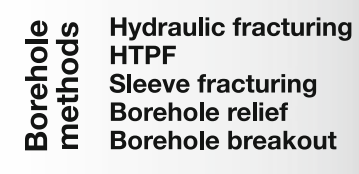 & \multirow{6}{*}{$\begin{array}{l}\text { ISD Model } \\
\text { Hydraulic fracturing } \\
\text { HTPF } \\
\text { overcoring } \\
\text { focal mechanism } \\
\text { fault slip analysis } \\
\text { others } \\
\text { Numerical } \\
\text { Modeling } \\
\text { rock mechanic } \\
\text { parameters } \\
\text { boundary conditions } \\
\text { geometry } \\
\text { software (BEM, DEM, } \\
\text { FEM, etc.) }\end{array}$} & \\
\hline \multirow{3}{*}{$\begin{array}{l}\frac{\pi}{\pi} \\
0 \\
\overline{0} \\
\frac{0}{0} \\
\frac{0}{0} \\
\frac{d}{0} \\
\frac{0}{0} \\
\frac{0}{0} \\
\frac{0}{0} \\
\frac{5}{0} \\
\frac{2}{2}\end{array}$} & $\begin{array}{l}\text { Morphology } \\
\text { Topography } \\
\text { Glacial effects } \\
\text { Ulift } \\
\text { Subsidence }\end{array}$ & $\begin{array}{l}\text { ASR, DSA, DSCA, } \\
\text { DWVA, WVA, DIF } \\
\text { Core Disking } \\
\text { Kaiser Effect }\end{array}$ & & \\
\hline & $\begin{array}{l}\text { Lithology } \\
\text { rock types } \\
\text { extension } \\
\text { boundaries } \\
\text { anisotropy }\end{array}$ & \multirow[t]{4}{*}{$\begin{array}{l}\text { Earthquakes } \\
\text { FIS, MIS, RIS }\end{array}$} & & \\
\hline & $\begin{array}{l}\text { Stress Decoupling } \\
\text { Geological } \\
\text { Structures } \\
\text { faults } \\
\text { veins } \\
\text { dykes } \\
\text { fracture zone } \\
\text { joints }\end{array}$ & & & \\
\hline \multirow{2}{*}{ 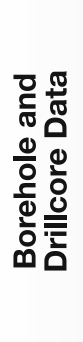 } & $\begin{array}{l}\text { Borehole Data } \\
\text { stability } \\
\text { breakout } \\
\text { fault slip analysis } \\
\text { rock quality } \\
\text { groundwater }\end{array}$ & & & \\
\hline & $\begin{array}{l}\text { Core Data } \\
\text { core disking } \\
\text { fault slip analysis }\end{array}$ & & & \\
\hline \multicolumn{2}{|c|}{ (1) Existing Data } & (2) New Data & (3) Integrated & (4) Final Data \\
\hline
\end{tabular}

step, data from different stress sources (focal mechanism, fault slip analysis, borehole breakouts), information from the BESM and the results from the different stress measurement methods are merged (e.g. Cornet and Burlet 1992; Tonon and Amadei 2003; Wileveau et al. 2007). Numerical stress models can be of great help in predicting and validating the in situ stress and together with the results of the stress measurements and ISD, it supports the establishment of the final rock stress model (FRSM) as presented in Fig. 1. The scaling relationship is also illustrated in the figure. The scale of the problem is defined by the distribution of the available data and the objective of the BESM is to help identify if all data can be assumed to sample the same continuum, or if the data needs to be divided into subsets, which is then followed by the ISD phase. Once completed, the drastic change from the conventional single method approach concerns the precision and credibility of the in situ stress. A site with different single method interpretation of various locations in space and time now has to become one ISD solution. This is the difficult task of the multiple-method, scaled, integrated approach. Geological field data and information from borehole and core data, together with old and new stress measurement data, are often point wise information. After performing the integrated stress determination (ISD) and stress modeling, the resulting stress data are relevant for larger rock volume and therefore are more adequate for the design and construction at a site or an area. 


\section{Best Estimate Stress Model}

The data collection for establishing the best estimate stress model (BESM) can be divided into three main groups: (a) data extraction, (b) morphological/geological data, and (c) borehole and drill core data (Fig. 1).

The items listed in the left column of the boxes in Fig. 1 can serve as a checklist in performing the first step in a stress analysis for a site or an area. After collecting the data and performing the mapping and analysis, the BESM can be established and the model should result in the best estimate of stress orientation and magnitude versus depth. Before any in situ stress measurements at a site, establishment of BESM is recommended.

\subsection{Data Extraction: Classes of Stresses}

The first step in establishing the BESM, requires an assessment of the type of stresses that can exist at the site or in an area. There is no internationally agreed terminology and scheme for the different type of stresses existing in the Earth's crust. Recently, Zang and Stephansson (2010) presented a rock stress classification and terminology as shown in Fig. 2. The first level of stresses distinguish between in situ and perturbed in situ stresses and for anisotropic or heterogeneous rock material the term structural or perturbed structural stress has to be used. Note that depending on the distance from the heterogeneity we distinguish between near-field stresses, i.e. the local stress perturbation in the vicinity of the heterogeneity, and farfield stresses, i.e. the global stresses applied at infinity (regional). Near-field stresses decrease rapidly with distance from the defect (fault, heterogeneity). To separate out different components in the stress tensor (e.g. a regional horizontal stress which is locally perturbed by a fault), one has to operate at different scales, Sect. 2. The four secondlevel force contributors (A1-A4) to the in situ stress tensor are originating from different forces in the Earth's crust. On the third hierarchical level, active tectonic stresses due to present state straining of the Earth's crust are divided into first order (plate scale), second order (mountain range), and third order (fault scale) stresses. The different orders of tectonic stresses are scaled according to their coherent domain in the region in which a stress component is supposed to be uniform, both in magnitude and orientation. Figure 2 illustrates the broad scale and local active forces responsible for the stresses of first- and second order in the context of modern plate tectonics. The third-order stress patterns in Fig. 2 are explained by faults, seismic-induced stress changes due to large earthquakes and volcanic eruptions, as well as local density contrast, e.g. from salt diapers or detachment horizons (Heidbach et al. 2007, 2010). For applied rock mechanics and rock engineering purposes, gravitational and tectonic stresses are by far the most important (Fig. 2A1, A2).

\subsection{Data Extraction: Stress Data and World Stress Map}

Many authors have collected and summarized data on rock stresses and proposed expressions for the variation of the magnitude of the vertical and horizontal stresses with depth at specific sites and/or regions of the world. A summary of references to publications of horizontal and vertical stress versus depth, magnitude-depth profiles and stress orientation maps are presented in Amadei and Stephansson (1997) and Zang and Stephansson (2010), respectively. When estimating the state of stress at any depth in the rock mass, we make the assumption that the in situ stress can be described by three components: a vertical component due to the weight of the overburden at that depth and two horizontal components which are larger or smaller than the vertical stress. For the variation of vertical stress with depth, there has been a long series of in situ stress measurements conducted and several data compilations done (Herget 1974; Brown and Hoek 1978; Amadei and Stephansson 1997; Zang and Stephansson (2010)), that proofs that, in most cases, the magnitude of the vertical stress can be explained by the overburden weight only. Deviation from this rule exists and in particular in areas of young tectonics, volcanism, rough topography and near major discontinuities in the rock mass. Relationship between vertical and horizontal stress for simple, elastic, homogeneous Earth, and rock masses with transversely and orthotropic anisotropy are presented in Zang and Stephansson (2010), and in more details in Cornet and Burlet (1992). The authors, Amadei and Stephansson (1997) and Zang and Stephansson (2010) have pointed out that the generic, often linearly increasing stress magnitude versus depth relationships presented should be used with caution, as they are usually associated with scatter. The stresses at a site can vary locally due to topographical effect, geological unconformities, stratification, geological structures such as faults, dikes, veins joints, folds, etc. Therefore, in estimating the state of stress at a site or a region, these local perturbations need to be considered as they cause deviation from the often-assumed linearity of stress variations with depth. Measured variations of stress with depth have also demonstrated "stress decoupling" (Haimson 1980; Martin and Chandler 1993; Stephansson 1993; Roth and Fleckenstein 2001), where stresses at shallow depth might be entirely different from stresses at great depth. Stress decoupling is valid for both stress magnitude and orientation. The World Stress Map (WSM) is the global database for contemporary tectonic stress data from the Earth's crust (Zoback et al. 1989; Heidbach et al. 2008). Various academic and industrial institutions working in different 
Fig. 2 Rock stress scheme and terminology at three hierarchical levels. Level 1 separates solid $(A C)$ from excavated rock mass $(B D)$. Level 2 separates in situ stress components according to their origin forces. Level 3 separates tectonic stresses according to their coherent domains, such as plate tectonics, isostacy and individual faults, after Zang and Stephansson (2010)

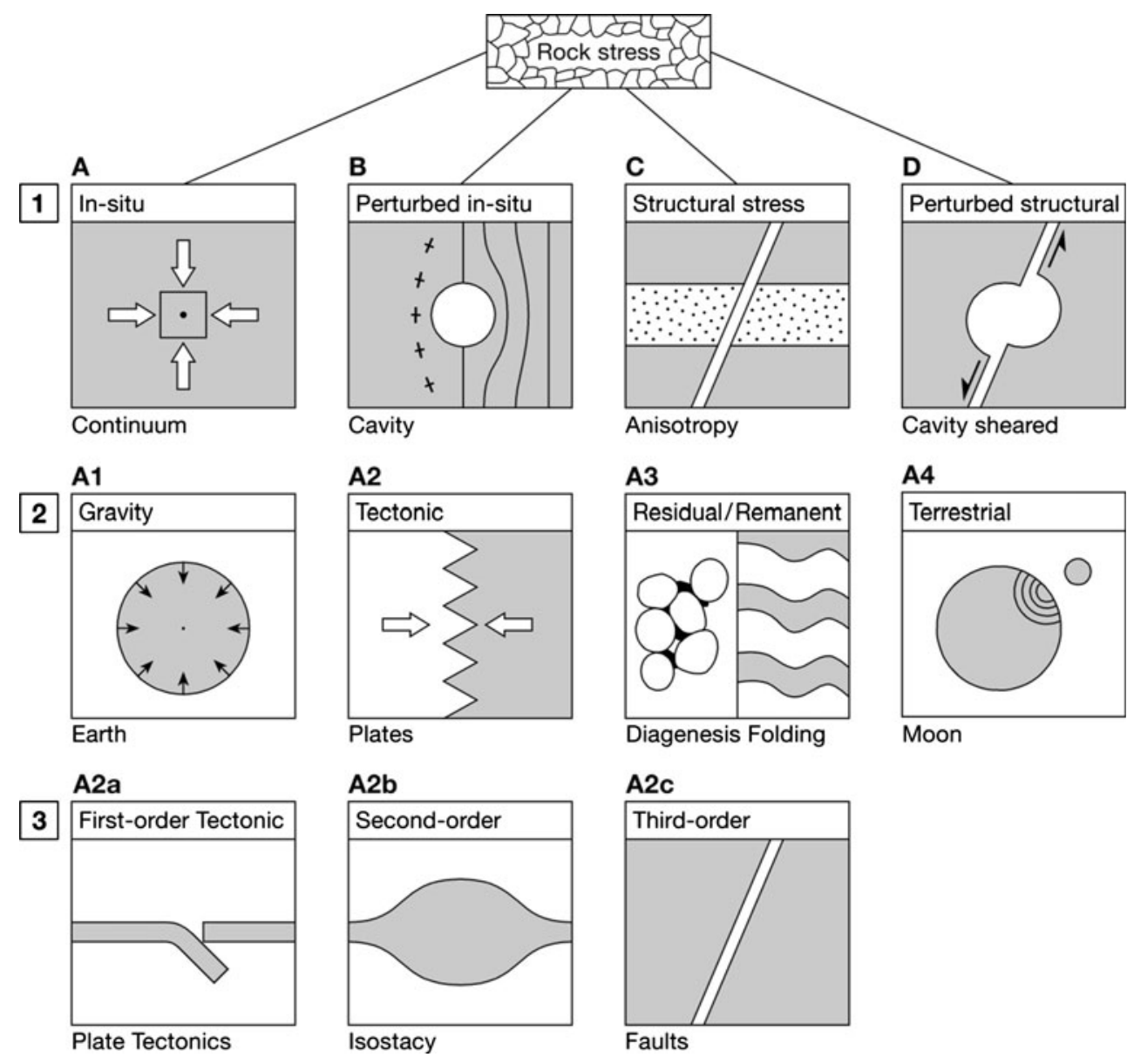

disciplines of Earth sciences, such as geodynamics, hydrocarbon exploitations and rock engineering use the WSM. The uniformity and quality of the WSM is guaranteed through (1) quality ranking of the data according to international standards, (2) standardized regime assignment, and (3) guidelines for borehole breakout analysis and other methods. To determine the tectonic stress orientation, different types of stress indicators are used in the WSM. The 2008 release of WSM contains 21,750 data points and they are grouped into four major categories with the following percentage (http://www.gfz-potsdam.de) (Heidbach et al. 2010): (1) Earthquake focal mechanisms (72\%), (2) wellbore breakouts and drilling induced fractures $(20 \%)$, (3) in situ stress measurements [overcoring, hydraulic fracturing, borehole slotter (4\%)], and (4) young geologic data [from fault slip analysis and volcanic vent alignments $(4 \%)]$.

The seismologists and their analysis of the focal plane mechanisms related to large earthquakes (Angelier 2002) provide the majority of data to the WSM. The relatively small percentage of in situ stress measurements is due to the demanding quality ranking and the fact that many of the data are company owned. At the very first stage of estimating the state of stress at a site or a region, consultation of the WSM is appropriate and often worthwhile. A detailed map of the area of interest can be provided free by the WSM. The delivered map contains a legend of the most likely type of stress regime (normal, strike slip and thrust faulting regime) in the area. Data can also be extracted from different depth interval and for different stress recording methods. If there is enough stress data from a region, a map of smoothed direction of maximum horizontal stress can be ordered (Fig. 3). In using stress data from the WSM, it is important to consider the depth for which the stress data are relevant.

\subsection{Morphology and Geology}

The issue of morphology and topography on estimating in situ stress is of particular interest in mountainous area, near valley slopes and at the top of high mountains and for mining projects, e.g. at the slopes of open pit mines. The slopes and valley sides can create stress perturbations of underground excavations located at the toe of the slopes and valleys and cause rock burst and spalling and other types of rock failure. It is a difficult task to determine analytically the in situ stress field in a rock mass or a region with an irregular surface using the theory of linear 
Fig. 3 Smoothed maximum horizontal stress direction map of Western Europe (short bars) based on the 1,721 stress entries from the World stress map. Thin grey lines show the relative plate motion trajectories of the African plate with respect to the Eurasian plate, modified from Heidbach et al. (2007) and after Zang and Stephansson (2010)

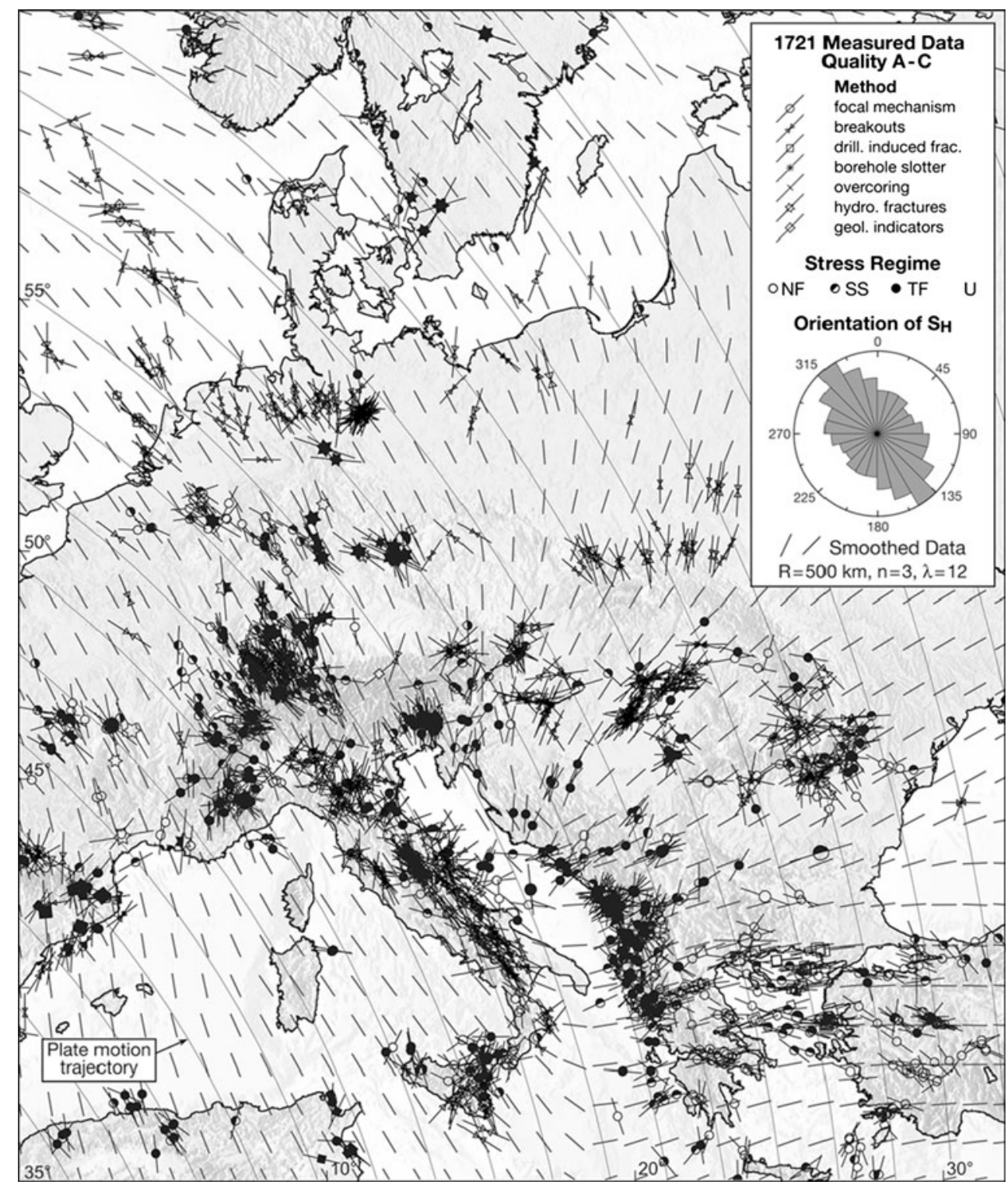

elasticity. The difficulty of determining stresses in regions with rough topography is due to the fact that the Earth's surface is a principal stress plane where shear stress is zero. A summary of the developments and their application to different topography and gravity and tectonic loadings and rock mass anisotropy is presented in Amadei and Stephansson (1997). All the derived analytical expressions predict tensile stress in the valley bottom and this is supported by the observations from the field in terms of a zone of fractured and loose rock masses and tendencies of upwarping phenomena in the bottom of valleys. In steep mountainous areas or rock slopes, the gravity loading alone cause high stress concentrations parallel with the surface of the slope. In rock engineering, the stress deflection caused by these slopes has a tendency to cause spalling in the walls of a tunnel (Myrvang 1993). Spalling is a common phenomenon in valley tunnels across the fjords in Norway and in valleys of young mountainous areas where topography is steep and rough. The simplifying assumption that the principal rock stresses are vertical and horizontal with depth and that the vertical stress is equal to the weight of the overburden is not valid for areas with gentle to strong topography. The influence of morphology and topography has to be included in establishing the best-estimate stress model (BESM). Glacial effects, uplift and subsidence very often cause a more intense fracturing and faulting in the uppermost parts of the Earth's crust. This disturbs the stress field so that for example in glaciated terrains like Scandinavia and Canada one often finds an excess of horizontal stresses and thrust faulting conditions in the uppermost couple of hundred meters of the rock (Stephansson 1993). 


\subsection{Geological Data}

Understanding the geological history of a site or an area is essential as it can be used to determine the evolution of the stress regime in which the site or area of interest is located. No one should run a stress estimation campaign and produce a model without studying the geology carefully and understanding its ramifications. Such an approach has been applied recently to the area at Äspö Hard Rock Laboratory in Sweden (Hakami et al. 2002). A methodology for building a stress model has been suggested that involves different steps, starting with preliminary stress estimation, followed by steps for interpreting site-specific information. Factors that might influence the regional stresses and the in situ stresses at the site are listed. Because the Fennoscandian Shield, where Äspö is located, is a part of the Eurasian plate its geological history is presented in the context of plate tectonics. The role of current plate motion for the present day state of stress in the NW European sub-plate is highlighted (see also Fig. 3). The report by Hakami et al. (2002) is one of the very first attempts ever made to present a plan for a complete stress model of a specific site and where the tectonics and structure geology play an important part. With respect to determination, the magnitude of the stresses with reasonable certainty, the authors (Hakami et al. 2002) advocate that in situ stress measurements should be used. Estimating in situ stresses requires a detailed characterization of the site geology like lithology and lithological boundaries, its tectonic history, critical structures, erosion, uplift, influence of glaciation, hydrogeology, neo-tectonic and others. In the following sections, a few of the most important geological factors to rock stress estimation are considered.

\subsection{Lithology and Lithological Boundaries}

In situ stresses can vary significantly from one lithological unit to the next depending on the relative stiffness and strength between the individual rock masses. Abrupt changes are likely to appear at the contacts between different lithological units (e.g. Tonon and Amadei 2003; Wileveau et al. 2007). Therefore, it is of utmost importance to perform a correct geological mapping and characterization of the site or area. The influence of lithology on the distribution of horizontal stress at depth has been demonstrated by a large number of stress measurements conducted in sedimentary and volcanic rocks. A list of references is presented by Amadei and Stephansson (1997). In general, one expects to find larger stress magnitudes in the more competent strata as stresses tend to concentrate in hard rocks surrounded by less competent rocks and subjected to the same far-field stress field. However, there have been reported results from hydraulic stress measurements where instantaneous shut-in pressure was found to be lower in layers with high Young's modulus and low Poisson's ratio and higher in layers with low Young's modulus and high Poisson's ratio (Amadei and Stephansson 1997). Similar results have also been reported for sedimentary rocks in tectonically relaxed areas. However, these are exceptions and in general, higher modulus rock types are more likely to carry higher than average stresses. The term structural stress (see Sect. 3.1) was introduced by Jaeger and Cook (1979). Structural stresses are caused by anisotropy and heterogeneity of rock mass and are depicted from Zang and Stephansson (2010) with and without externally applied loads in Fig. 4. Principal stress orientation at selected points are oriented parallel to the applied load for the homogeneous material (Fig. 4a, d). In the case of anisotropic material, the applied far-field stress is perturbed by the planes of anisotropy and principal stress orientation in the material is rotated towards the orientation of the rock anisotropy (Fig. 4b, e). In case of heterogeneous material (Fig. 4c, f) orientation and magnitude of stresses are perturbed in the vicinity of the defect. As a rule of thumb, far-field stresses can be treated as undisturbed at distances of about three times the diameter of the defect.

\subsection{Different Stress Regimes and Stress Decoupling (Near-Field and Far-Field Stress)}

From the results of stress measurements in vertical boreholes, it has been demonstrated that the type of stress regime at shallow depth may be entirely different from the stress regime at great depth. A recent example is described from the stress measurements for the Björkö geothermal project in the vicinity of Stockholm, Sweden (Ask and Stephansson 2003). Here, the stresses in the uppermost $400-500 \mathrm{~m}$ are characterized by a thrust faulting stress state, where the vertical stress is the minimum principal stress. Below ca. $500 \mathrm{~m}$ depth, the stress state corresponds to a strike slip stress regime where the vertical stress is the intermediate principal stress. The stress measurements were conducted in the centre of the Björkö meteoritic impact with an estimated diameter of $10 \mathrm{~km}$. The granitic rocks are severely fractured due to the impact. Another of the Swedish meteoritic impacts, the Siljan impact structure in central-north Sweden shows a similar stress change with depth (Lund and Zoback 1999). Both impact structures indicate somewhat lower stress magnitudes as compared to the general situation in Fennoscandia. A similar stress change with depth to that observed at Siljan and Björkö in Sweden has been shown among others for the site investigations of the geothermal project in the Carnmenellis granite, Cornwall, UK (Cooling et al. 1988). These types of different stress regimes with depth are referred to as stress decoupling and can occur for various reasons, e.g. a 
Fig. 4 Homogeneous (a), anisotropic (b), and heterogeneous (c) material affect principal stress orientation and magnitude (d-f), after Zang and Stephansson (2010)
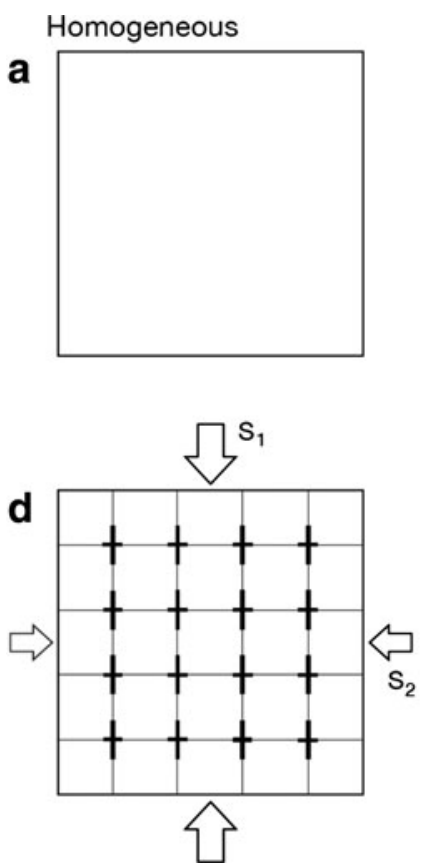

marked hiatus in the stratigraphy like a basement-cover situation, different lithology in a rock sequence, non-persistent far-field boundary stresses, post-glacial lithosphere flexure and major discontinuities intersecting the area. Post-glacial lithosphere flexure and the transition from more fractured rock mass to less fractured rock of the glaciated terrains is the most likely explanation for the stress change with depth for the three mentioned sites. An interesting study related to stress decoupling in the PermTriassic rocks of the eastern part of the North German Basin (ENGB) is presented by Roth and Fleckenstein (2001). From the data collected in the WSM project, it is known that central Western Europe is dominated by a NWSE to NNW-SSE orientation of the maximum horizontal compressive stress (cf. Fig. 3), the result of ridge push from the North Atlantic and the northward drift of Africa (Müller et al. 1992). From a new analysis of four-armdipmeter data and televiewer loggings at intervals from 1,500 to $6,700 \mathrm{~m}$ in deep boreholes and comparison with hydraulic fracturing stress measurements from the region, the substrata below the more than 1,000 m thick Zechstein salt formation is dominated by a NNE-SSW striking orientation of the maximum horizontal stress. The $45^{\circ}-90^{\circ}$ difference in stress orientation above and below the detachment of the Zechstein salt formation is explained by decoupling of stresses (Fig. 5). Roth and Fleckenstein (2001) have suggested three hypotheses for this stress decoupling: (1) the influence of the large ancient suture zones, a trans-European fault zone and the Elbe fault system, with a NW-SE strike and bordering the basin; (2) dominance of local stresses due to postglacial lithosphere flexure where the compressive stresses outside the edge of
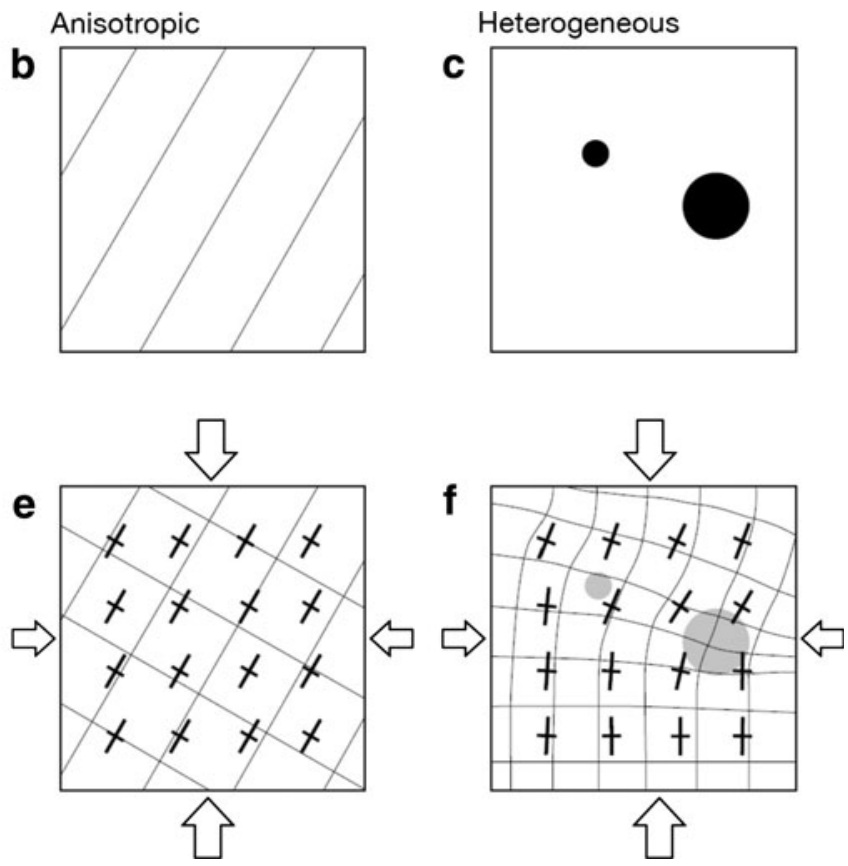

the Weichselian and earlier Fennoscandian ice sheets might have caused the reorientation of the stress field in the subsaline formations; (3) a strong lithosphere barrier below the northern margin of the basin, derived from rheology/depths profiling and modeling, which proves that stresses are attracted and reoriented to the observed $\mathrm{N}-\mathrm{S}$ orientation. In conclusion, as there is no indication for stress differences from the plate boundaries, the stress decoupling in ENGB is likely to be due to contrast in competence (rigidity) between sedimentary rocks in North German Basin and the more competent basement of Fennoscandian rocks.

\subsection{Stress Perturbation from Fault \\ (Near-Field and Far-Field Stress, Continued)}

Geological structures, such as faults, folds, dikes, veins, sills, fault striation or slickensides have long been used by structural geologists to indicate the paleo-stress, i.e. the state of stress prevailing at the time of genesis of the structure. Since the stresses that created the structure may have been modified due to later tectonic events, erosion, uplift, and glaciation, etc. the structure and petrography fabric might not be correlated at all with the current stress field. To determine the contemporary stress field, one has to seek out the most recent geological structures and use as stress orientation indicators. As an example, different volcanic vent alignments and inversion of fault-slip data are used for stress orientation in the WSM database (Heidbach et al. 2008). Fault-slip analysis, as developed by Angelier (1989) and others for stress analysis of recent geological formations or inversion of data from slickensides on fracture surfaces in oriented drill core samples (Hayashi and 
Fig. 5 Decoupling of stress in the eastern part of the North German Basin: a stress data entries from World Stress Map, b smoothed maximum horizontal stress orientations, c block diagram of geology and far-field stress orientation in the sub-reservoir rock and decoupled stress in the overburden, after Heidbach et al. (2007) and modified by Zang and Stephansson (2010)

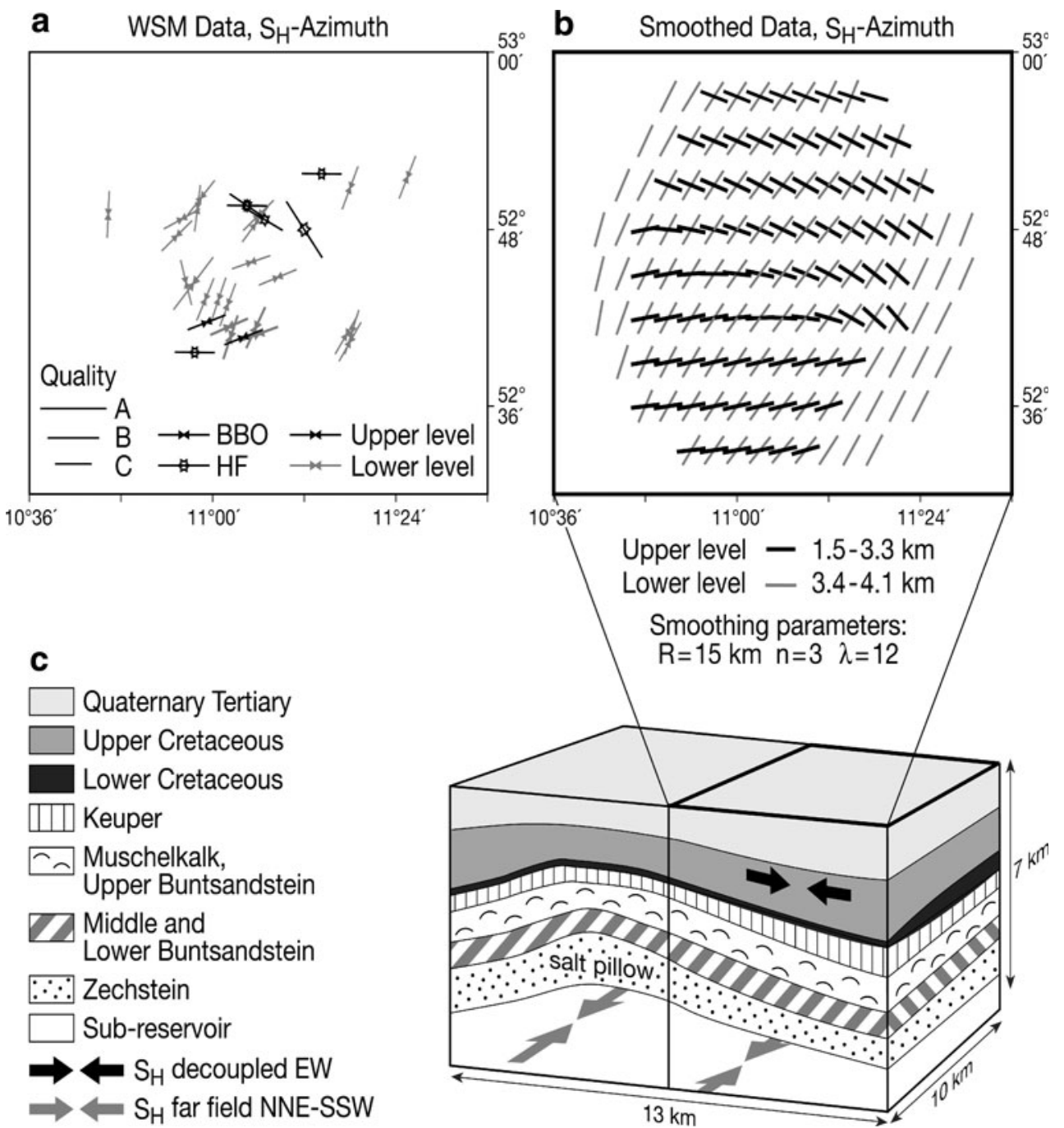

Masuoka 1995) are powerful tools in stress determination of a site or an area. The existence of geological structures and heterogeneities will affect the distribution and magnitude of in situ stresses and make the local stress field different from the regional stress field. When a regional stress field is approaching a major discontinuity, the stress transfer across the stress perturbation from the discontinuity is very much dependent upon the material property of the discontinuity. If it happens to be an open structure the stresses cannot transect it. If the structure has the same properties as the surrounding rocks, the stresses are unaffected. If the material in the discontinuity is more rigid than the surrounding rock mass the maximum principal stress is diverted perpendicular to the discontinuity and if it is less rigid the maximum stress will tend to divert parallel with the discontinuity. The classical example of the second situation is the stress field in the surrounding of the San Andreas Fault system often referred to as a weak fault in a strong crust (Hickman and Zoback 2004). The ongoing San Andreas Fault Observatory at Depth (SAFOD) project in the central part of the fault is motivated by the need to answer fundamental questions about the physical processes, including rock stresses, controlling faulting and earthquake generation within a major plate-bounding fault. In Japan, at a somewhat smaller scale, Sugawara and Obara (1995) demonstrated using overcoring that the least principal stress acted perpendicular to the Atotsugawa fault plane, in an area otherwise dominated by thrust faulting. Lin et al. (2010) found the localized rotation of principal stress around faults and fractures from borehole B of the Taiwan Chelungpu-fault drilling project. In this study, borehole breakouts and drilling-induced tensile fractures were used together with electrical images and photographs of the borehole wall to determine the relationship between faults 
Fig. 6 Correlation of the direction of the maximum horizontal stress and the strike orientation of faults in the northern British North Sea sector, from Yale (2003)

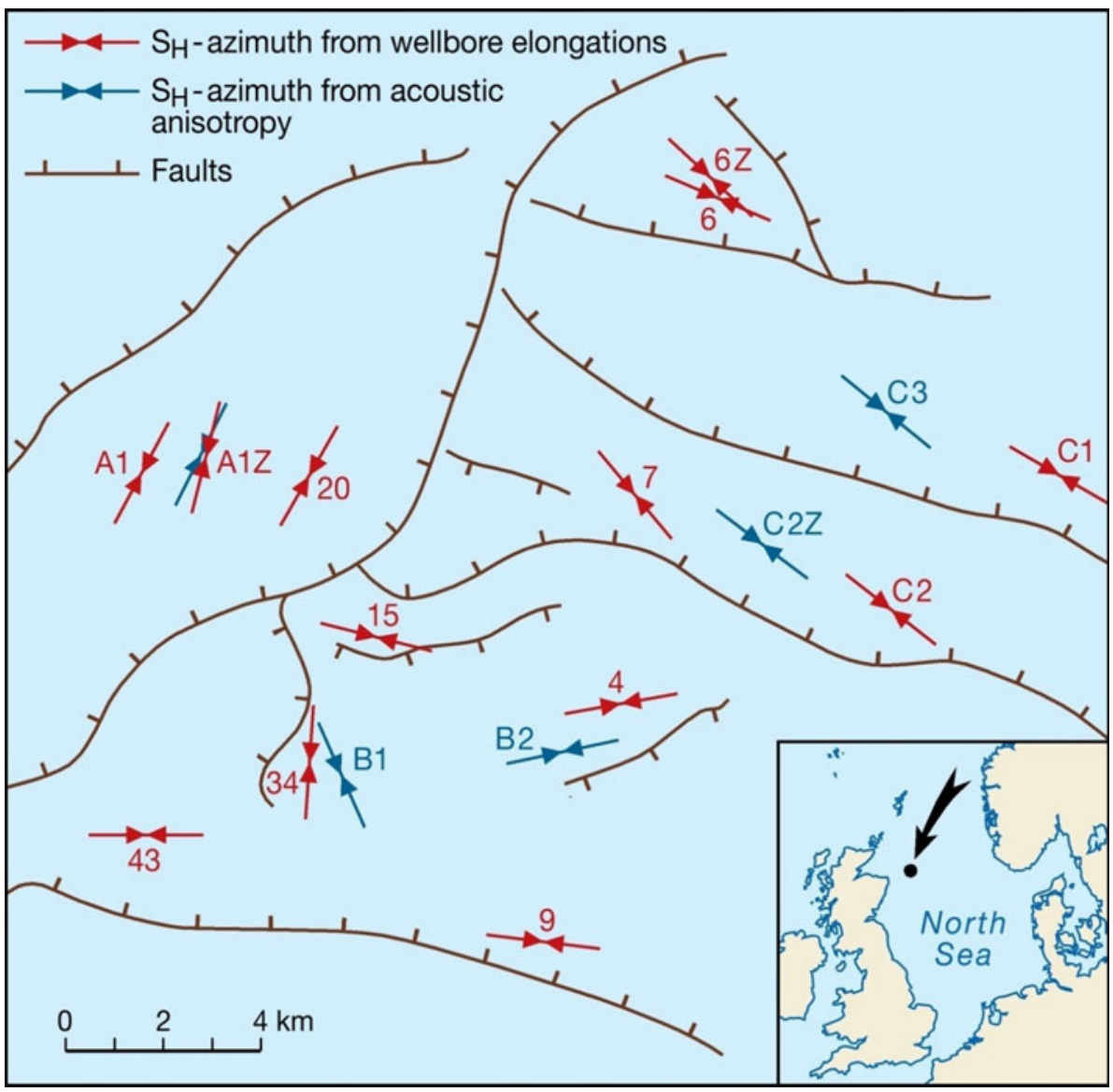

variation between the far-field and the near-field stress strongly suggests a rotation of the in situ stress field by the local fault structure. The very large throws on these faults and the strong segmentation of the field may be the cause of the observed in situ stress rotation in this area (Yale 2003).

Stress relief from neotectonic faulting in the northern parts of the Fennoscandian Shield has been reported by Amadei and Stephansson (1997) and Bjarnason et al. (1989). Measured stresses with hydraulic fracturing method in a borehole adjacent to the neotectonic, postglacial Landsjärv fault show a marked stress magnitude anomaly compared to the average state of stress in Fennoscandia (Fig. 7). Magnitude of both minimum and maximum horizontal stress is reduced to half the expected value close to the fault at about $500 \mathrm{~m}$ depth. Faults, fracture zones and dikes intersecting the rock mass at a site or region cause perturbation of the regional stress state. The amount of perturbation is very much governed by the strength and deformability of the discontinuity. Here, we are faced with the problem of lack of strength and stiffness data about large structures and sometimes the difficulty in determining their orientation in space. Sometimes, the application of simple numerical models of generic type can be of great value in analyzing the stress perturbation from planar structures (Su and Stephansson 1999). 
Fig. 7 Hydraulic stress measurements adjacent to the Lansjärv neotectonic fault, northern Sweden. Average hydrofracturing stress data from Fennoscandia (solid lines) are shown to illustrate the anomaly of stress magnitudes at the fault, after Bjarnason et al. (1989) and modified by Zang and Stephansson (2010)

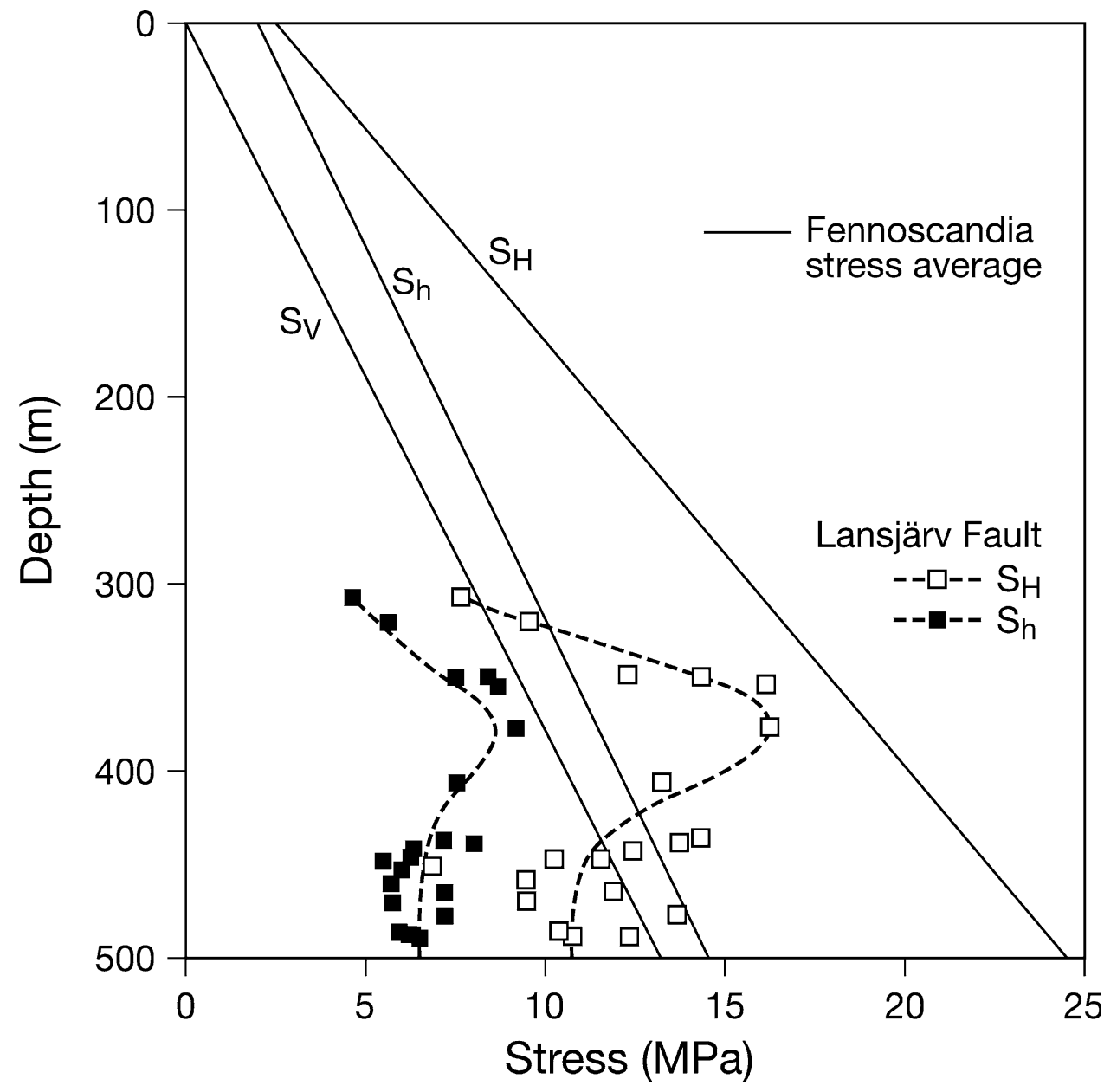

\subsection{Borehole and Drill Core Data}

Information from borehole and drill core data is important for the establishment of BESM. Borehole instabilities and breakouts and fault slip developed in the wall of the borehole give information about orientation of stresses. Sometimes the magnitude of stresses can be estimated from the shape of the breakout in combination with numerical modeling (Shen 2008). Observation of the geometry of core disking and fault slip on drill cores provide data relating to the magnitude and orientation of the stresses in the plane perpendicular to the drill core axis. Borehole breakout is now an established method to estimate the orientation of the maximum and minimum principal stresses in the plane perpendicular to the borehole axis. The breakouts are enlargements of the borehole wall occurring $180^{\circ}$ apart, caused by stress-induced failure of the wells. In vertical wells, the diametrically positioned zones of broken or fall-out rock material occur at the azimuth of minimum horizontal compressive stress and typically have a consistent orientation in a given well or field. The shape and depth of the breakouts depend on the type of rock and the magnitude of in situ stress. Hard rocks and high stresses tend to generate deep breakouts with relatively small breakout angle. Breakouts can have a length of between centimeters up to several hundred meters. Borehole breakouts in a well can be visualized using optical (camera), mechanical (caliper) or electrical resistivity (formation micro-scanner) and ultrasonic image (borehole televiewer) tools (Ellis and Singer 2007). A summary of theories of breakout formation, laboratory studies, techniques, equipment and evaluation procedures are presented in Amadei and Stephansson (1997) and Zang and Stephansson (2010). If data of borehole breakouts exist from a site, the information is of great value for the delineation of the stress orientation of the BESM.

Once drill cores are available from a site or an area, the search for and analysis of core disking should be included in the stress estimation program. Core disking is often an indication of high horizontal stresses and the geometry of the disks and the orientation of the disk saddle are indicators of stress orientation. The core breaks up into disks that are usually curved with the centre of curvature oriented towards the bottom of the borehole. The orientation of the 
crest line of the curved disk surface tends to coincide with the direction of the maximum principal stress. Laboratory testing and later numerical modeling has shown that once the radial stress in the core trunk during drilling exceeds the compressive strength of the rock core, disking starts to develop. Haimson and Lee (1995), in their study on core disking, proposed that thinner disks are indicative of higher horizontal stresses and that the through axis of saddleshaped core disks often is aligned with the orientation of the maximum horizontal in situ stress. Less regular core disking might also develop due to existing discontinuities or fabrics in the rock mass. The application of high thrust during the drilling operation can form horizontal tensile stress at the root of the drill core which is sufficiently large to generate extensile micro-cracks that coalescence to cause core disking (Kutter 1993; Hakala 1999). Matsuki et al. (2004) estimated the directions of three-dimensional in situ stresses from the height at the periphery of the end surface of the core disks investigated. They applied the method to rock disks of diorite and granite from a vertical borehole (SB1) at Sakuma, Shizuoka prefecture, Japan where hydraulic fracturing was carried out to measure horizontal stress. Lim and Martin (2010) investigated the phenomenon of disking, and its relationship with stress magnitudes, in cores from 75-mm diameter boreholes in the Canadian Underground Research Laboratory (URL). The data suggests that disking in Lac du Bonnet granite initiates when the maximum principal stress normalized to the Brazilian tensile strength exceeds 6.5.

\section{Stress Measurement Methods (SMM)}

It is our recommendation that rock stress measurements should be performed after the establishment of the best estimate rock stress model. Data and information collected for BESM can also be used in selecting the best suited method for in situ stress measurement(s) and/or core-based stress measurement(s). The authors (Amadei and Stephansson 1997) and more recently (Ljunggren et al. 2003; Zang and Stephansson 2010) have presented overviews of the most important stress measurement methods. Rock stress measurements in the Earth's crust can be classified according to their underlying physical principle, or according to the rock volume involved in the measurement technique. Crustal stress measurement techniques can be grouped into five different categories according to physical mechanism, experimental technique and ultimate borehole depth (see Table 7.1 in Zang and Stephansson (2010)). Category (1) mechanism is related to rock fracture as applied to boreholes. The most important method of this category is hydraulic fracturing (HF) (Haimson 1978; Amadei and Stephansson 1997;
Zang and Stephansson 2010) where the minimum stress and the orientation of the maximum stress perpendicular to the borehole axis is determined. One modification of the $\mathrm{HF}$ test is hydraulic tests on pre-existing fractures (HTPF) (Cornet and Valette 1984; Haimson and Cornet 2003). The fluid pressure in HTPF balances exactly the normal stress across the pre-existing fracture. By combining pressure data from six or more fractures along the length of the borehole the 3D state of stress can be determined. When compared with HF, HTPF has the advantage of less limitation as regards geologic structures and the method does not require the determination of rock tensile strength. Another crucial issue with the HTPF technique is that it does not require that the borehole is aligned with a principal stress. Sleeve fracturing (Stephansson 1983), drilling-induced tensile fractures (Brudy and Zoback 1999) and borehole breakouts (Bell and Gough 1979) also belong to category (1) in the classification scheme.

Category (2) mechanisms are related to elastic strain relief due to coring. The technique can be further subdivided to surface relief methods, borehole relief methods and techniques that involve relief of large rock volumes with subsequent analysis of re-equilibrium deformation. Borehole relief methods can be further sub-classified according to the type of strain analysis at the borehole wall (see Zang and Stephansson 2010). Strains can be measured diametral (e.g. US Bureau of Mines USBM) or circumferential [e.g. Borre probe (Sjöberg et al. 2003)], at the flat end of the borehole (doorstopper), and at the surface of a conical or hemispherical end of a borehole (Obara and Ishiguro 2004). The Borre probe, the CSIR and CSIRO hollow inclusion cell are the most common tools applied in relief stress measurements (Sjöberg et al. 2003). Relief methods are the most widely used techniques in the engineering application of stress measurements for underground works.

Category (3) mechanism in the classification recommended by Zang and Stephansson (2010) is related to crack-induced strain relief in drill cores. Micro-cracking is generated in stress relief when the rock is cut from the in situ stress field at the bottom or the wall of a borehole. Core-based methods can be further sub-divided into the analysis of strain data like anelastic strain recovery (ASR), differential strain rate analysis (DRA), differential strain analysis (DSA), analysis of wave velocity data like differential wave-velocity analysis (DWVA) and wave velocity analysis (WVA). Cracking phenomena in drill cores and monitoring of related acoustic emissions by means of the Kaiser effect also belongs to this category (see Fig. 1, SMM).

Category (4) techniques, also called borehole seismic logging or indirect methods, combine the variation of 
physical rock properties with stress. Shear-wave polarization, shear wave splitting and analysis of Stonely waves are examples of wave propagation methods for stress analysis (Zang and Stephansson 2010). Finally, Category (5) techniques for stress estimates are concerned with physical properties of pre-existing fault zones in the Earth's crust and related earthquakes. The end members are fault plane solutions (FPS). Focal mechanisms of earthquakes provide the orientation of principal stresses and this information dominates the overall entries of stress data in the World Stress Map (WSM) described in Sect. 3.2. Guidelines for stress derivation from earthquake focal mechanisms are supplied on the WSM homepage (http://www.dc-app3-14. gfz-potsdam.de). Stress inversion from focal mechanisms can be separated into natural seismicity (NS) and induced seismicity (IS). In contrast to NS, the term IS refers to typically minor earthquakes and tremors that are caused by human activities that perturb the crustal stress field. Induced events are refined into mining-induced seismicity (MIS) and fluid-induced seismicity (FIS). MIS includes seismic events and related rock bursts arising from stress changes associated with mining activities. FIS is caused by injection of fluids in liquid waste disposal, or in the fracturing of hydrocarbon and geothermal reservoirs. Impoundment of large water reservoirs can generate FIS, and in this case are called RIS (reservoir induced seismicity). Stress inversions from induced seismic events, together with stress inversions from background natural seismicity, are useful tools to identify stress perturbations triggered by human activity (see Fig. 1, SMM).

By far the most extensive stress measurements campaigns and improvement of stress measurement techniques have been conducted for site investigations of underground laboratories and sites for final disposal of radioactive waste and spent nuclear fuel. One of the most important lessons learned from these site investigations is that it takes relatively long time and usually application of several different methods to obtain a reliable stress field of a site to host a deep geological repository of the size of about $1 \mathrm{~km}^{2}$ located at a depth of 400-500 m below the ground surface. For the case of the Forsmark site for final disposal of spent nuclear fuel, the Swedish waste handling organization SKB came to the conclusion after six years of site investigations (2002-2008) from the ground surface that the stress field and in particular the magnitude of stresses at repository level has to be defined in conjunction with the future tunneling and underground works. SKB started to use overcoring measurements with the Borre probe (Sjöberg et al. 2003) in deep boreholes later followed by hydraulic fracturing and HTPF (Haimson and Cornet 2003). The overcoring measurements gave core disking below the depth of ca. $200 \mathrm{~m}$ and the successful measurements above were recorded in exfoliated rock mass and therefore not relevant for the depth of the repository. Despite the problems with the overcoring method, the presented stress model for Forsmark is based on the overcoring data, core disking and the absence of borehole breakouts (SKB 2008). The hydraulic methods resulted in stress magnitudes about half the values of overcoring.

\section{Integrated Stress Determination Method (ISD) and Numerical Analyses}

The method of integrating the results of various stress measurement data obtained from applying different techniques to obtain a more reliable assessment of the in situ state of stress was introduced in the mid-1980 s and is still under development. In the early days, the integration method was based on a least square criterion (Tarantola and Valette 1982) where all measurements were assumed to obey a Gaussian distribution. In 1993, Cornet (1993) presented the HTPF stress determination method together with the Integrated Stress Determination Method. Data from hydraulic fracturing (HF) and hydraulic testing on pre-existing fractures (HTPF) were integrated in order to obtain a better indication of the regional stress field (farfield). Integration of the hydraulic fracturing (HF) and HTPF data at the Äspö Hard Rock Laboratory in Sweden was presented in Ask et al. (2001). The same type of integration was carried out at two sites in southern France (Ask et al. 2003) and for the geothermal project on Björkö, Sweden (Ask and Stephansson 2003). The integration of CSIR and CSIRO overcoring stress data from Äspö Hard Rock Laboratory was presented in Ask et al. (2001) and integration of HF, HTPF and overcoring data on each side of the major fracture zone NE-2 in Ask (2006).

Today the integration method ISD uses a variety of algorithms, although least-squares are dominating. There are also numerous sites where this type of integration (ISD) has been applied. For example, Cornet and Burlet (1992) applied the integration of HF-HTPF at eight different sites (four crystalline, four sedimentary rock) in France. Further, Yin and Cornet (1994) and Scotti and Cornet (1994) used information on induced seismicity and focal mechanisms to determine the in situ stress field in central France. A recent example for the "complete" determination of the in situ stress near the possible repository site for radioactive waste at Bure, NE France is given in Wileveau et al. (2007). In here, a combination of four different techniques; namely, HF, HTPF, sleeve fracturing and the analysis of en-echelon cracks were used in ISD to determine the in situ stresses within an argillite formation interbedded between two stiffer limestone layers, for the development and design of a underground research facility. 
Fig. 8 Numerical stress modeling with distinct element code 3DEC: a the model showing the orientation of the major fracture zones at the Forsmark site for spent nuclear fuel, Sweden, b overview of 3DEC model at the site, c principal stresses above and below a major shallow inclined deformation zone ZFMNE00A2 overlaying the rock mass for a future repository at $\sim 420 \mathrm{~m}$ depth, after Hakami (2006)
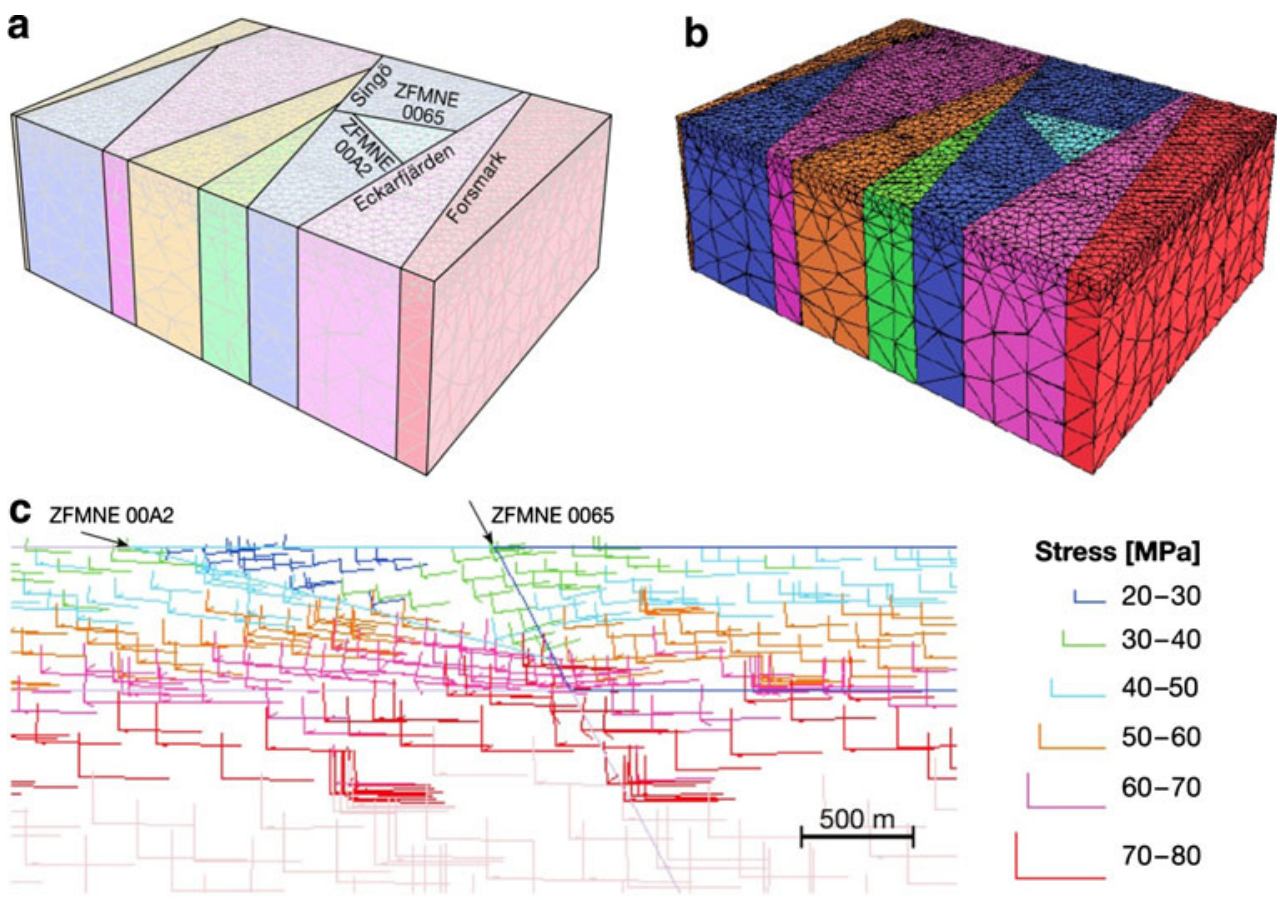

Numerical analyses employing a variety of simulation techniques (FEM, BEM, DEM, etc.) have been used in an attempt to predict or explain the in situ stress field and to illustrate the effect on the in situ stress of topography (Sturgul et al. 1976), stress distribution in a blocky rock mass subjected to a 2-D stress field (Stephansson et al. 1991), and the influence of large scale structures like faults (te Kamp et al. 1999). Inside and in the vicinity of faults and major fractures zones, both the stress magnitude and orientation will vary from point to point (Sect. 3.7). Stress prediction in these areas is more uncertain and even if it is possible to perform any stress measurements in these areas of poor rock quality, the variation in stresses will be larger. The numerical stress modeling shall help in obtaining an overall understanding of the state of stress between two points of stress measurements. The modeling results shall also contribute to the estimation of the variability of in situ stress magnitude and orientation in predicting the stresses in points or regions and uncertainty in presenting the final rock stress model. An example of stress modeling from the completed site investigations for the final repository of spent nuclear fuel at Forsmark, Sweden is illustrated in Fig. 8 (Hakami 2006). The site will host the Swedish repository of spent nuclear fuel. The 3DEC model shown in Fig. 8a consists of blocks with the same rock properties within a block surrounded by major deformation zones (faults). When equilibrium is obtained in the model the stress distribution is presented as a result, Fig. 8b. A detail of the orientation and magnitude of the maximum and minimum principal stresses for a region at a slightly inclined major deformation zone, called ZFMNE00A2, is presented in
Fig. 8c. Notice the rotation and reduction of the principal stresses in the hanging wall of the deformation zone. The final repository at Forsmark will be located $\sim 420$ m below surface and at the footwall side of ZFMNE00A2.

\section{Summary}

To reach the final rock stress model (FRSM) at the site or area in question (see Fig. 1), it is necessary to proceed in steps. (1) Define classes of likely stresses and collect all available stress data of the location and its surroundings. (2) Include topography, lithology and faults as well as borehole and drill core stress data (BESM). (3) Measure stresses at the site and determine vertical and horizontal stresses versus depth (SMM). (4) Combine available and measured in situ stress data with earthquake and fault related stresses and perform an integrated stress analysis (ISD). (5) Validate the results of the integrated stress analysis and generate a 2-D/3-D stress model with rock parameters measured, appropriate boundary conditions defined and solve the resulting momentum equations with appropriate numerical techniques and software. (6) Perform a sensitivity analysis, and (7) calibrate the model. Finally, it is necessary to consider the final near-field rock stress model in the context of the far-field stress pattern and present the stress model as principal or horizontal stresses versus depth (8) with clear indications of variability and uncertainty in magnitude and orientation. More detailed information on the procedures plus examples can be obtained from Zang and Stephansson (2010), and will be of 
major supplementary benefit to the readers of the SMPart 5.

Acknowledgments For constructive comments and thorough review of the manuscript we thank Daniel Ask (Pöyry SwedPower $\mathrm{AB}$, Luleå, Sweden), John W. Cosgrove (Imperial College, London, Great Britain), John A. Hudson (ISRM President), and Resat Ulusay (President of the ISRM Commission on Testing Methods).

\section{References}

Amadei B, Stephansson O (1997) Rock stress and its measurement. Chapman \& Hall, London

Angelier J (1989) From orientation to magnitudes in paleostress determinations using fault slip data. J Struct Geol 11:37-50

Angelier J (2002) Inversion of earthquake focal mechanism to obtain the seismotectonic stress IV-a new method free of choice among nodal planes. Geophys J Int 150:588-609

Ask D (2006) New development of the integrated stress determination method and application to rock stress data at the Äspö HRL, Sweden. Int J Rock Mech Min Sci 43:107-126

Ask D, Stephansson O (2003) Hydraulic stress measurements in borehole BJO01, Björkö impact structure, Lake Mälaren, Sweden. In: Sugawara K, Obara Y, Sato A (eds) International symposium rock stress, RS Kumamoto'03, Japan. Balkema, Rotterdam, pp 115-121

Ask D, Stephansson O, Cornet FH (2001) Integrated stress analysis of hydraulic and overcoring rock stress data in the Äspö region. Analysis of hydraulic fracturing stress measurements and HTPF in boreholes KAS02, KAS03, and KLX02. Swedish Nuclear Fuel and Waste Management Co, SKB International Progress Report, IPR-01-26, Stockholm

Ask D, Stephansson O, Cornet FH (2003) Integration of CSIR- and CSIRO-type of overcoring rock stress data at the Zedex Test Site, Äspö HRL, Sweden. In: Proceedings of tenth ISRM Congress, Johannesburg. Balkema, Rotterdam

Bell JS, Gough DI (1979) Northeast-southwest compressive stress in Alberta: evidence from oil wells. Earth Planet Sci Lett 45:475-482

Bjarnason B, Klasson H, Leijon B, Strindell L, Öhman T (1989) Rock stress measurements in boreholes KAS02, KAS03 and KAS05 on Äspö. Swedish Nuclear Fuel and Waste Management Co, SKB Progress Report 25-89-17, Stockholm

Brown ET, Hoek E (1978) Trends in relationships between measured in situ stresses and depth. Int J Rock Mech Min Sci Geomech Abstr 15:211-215

Brudy M, Zoback MD (1999) Drilling-induced tensile well-fractures: implications for determination of in situ stress orientation and magnitude. Int J Rock Mech Min Sci 36:191-215

Christiansson R, Hudson JA (2003) ISRM suggested methods for rock stress estimation-part 4: quality control of rock stress estimation. Int J Rock Mech Min Sci 40:1021-1025

Cooling CM, Hudson JA, Tunbridge LW (1988) In situ rock stresses and their measurement in the UK-part II. Site experiments and stress field interpretation. Int J Rock Mech Min Sci Geomech Abstr 25:371-382

Cornet FH (1993) The HTPF and the integrated stress determination method. In: Hudson JA (ed) Comprehensive rock engineering, vol 3, Pergamon Press, Oxford, pp 413-432

Cornet FH, Burlet D (1992) Stress field determination in France by hydraulic tests in boreholes. J Geophys Res 97:11829-11849

Cornet FH, Valette B (1984) In situ stress determination from hydraulic injection test data. J Geophys Res 89:11527-11537
Ellis DV, Singer JM (2007) Well logging for earth scientists. Springer, Dordrect

Haimson BC (1978) The hydrofracturing stress measurement method and recent field results. Int J Rock Mech Min Sci Geomech Abstr $15: 167-178$

Haimson BC (1980) Near surface and deep hydrofracturing stress measurements in the Waterloo quartzite. Int J Rock Mech Min Sci Geomech Abstr 17:1-88

Haimson BC, Cornet FH (2003) ISRM suggested methods for rock stress estimation-part 3: hydraulic fracturing (HF) and/or hydraulic testing of pre-existing fractures (HTPF). Int J Rock Mech Min Sci 40:1011-1020

Haimson BC, Lee CF (1995) Estimating in situ stress conditions from borehole breakouts and core disking. In: Matsuki K, Sugawara K (eds) Proceedings of international workshop on rock stress measurement at great depth, Tokyo, Japan, 8th ISRM Congress. Balkema, Rotterdam, pp 19-24

Hakala M (1999) Numerical study on core damage and interpretation of in situ state of stress. Posiva Rep 99-25, p 234

Hakami H (2006) Numerical studies on spatial variation of the in situ stress field at Forsmark a further step. Site descriptive modeling Forsmark-stage 2.1. Swedish Nuclear Fuel and Waste Management Co, SKB R-06-124 (downloadable from http://www. skb.se), Stockholm

Hakami E, Hakami H, Cosgrove J (2002) Strategy for a rock mechanics site descriptive model-development and testing of an approach to modeling the state of stress. Swedish Nuclear Fuel and Waste Management Co, SKB Research Report R-02-03 (downloadable from http://www.skb.se), Stockholm

Hayashi K, Masuoka M (1995) Estimation of tectonic stress from slip data from fractures in core samples. In: Matsuki K, Sugawara K (eds) Proceedings of international workshop on rock stress measurement at Great Depth, Tokyo, Japan, 8th ISRM Congress. Balkema, Rotterdam, pp 35-39

Heidbach O, Reinecker J, Tingay M, Müller B, Sperner B, Fuchs K, Wenzel F (2007) Plate boundary forces are not enough: secondand third-order stress patterns highlighted in the World Stress Map database. Tectonics 26:TC6014. doi:10.1029/2007TC00213

Heidbach O, Tingay M, Barth A, Reinecker J, Kurfeß D, Müller B (2008) The 2008 release of the World Stress Map. doi: 10.1594/GFZ.WSM.Rel2008

Heidbach O, Tingay M, Barth A, Reinecker J, Kurfeß D, Müller B (2010) Global stress pattern based on the World Stress Map database release 2008. Tectonophysics 482:3-15

Herget G (1974) Ground stress conditions in Canada. Rock Mech 6:53-74

Hickman SH, Zoback MD (2004) Stress orientations and magnitudes in the SAFOD pilot hole. Geophys Res Lett 31, L15S12. doi: 10.1029/2004GL020043

Hudson JA, Cornet FH, Christiansson R (2003) ISRM suggested methods for rock stress estimation-Part 1: strategy for rock stress estimation. Int J Rock Mech Min Sci 40:991-998

Jaeger JC, Cook NGW (1979) Fundamentals of rock mechanics, 3rd edn. Chapman \& Hall, London

Kutter HK (1993) Influence of drilling method on borehole breakouts and core disking. In: Wittke W (ed) Proceedings of 7th ISRM Congress, Aachen. Balkema, Rotterdam, pp 1659-1664

Lim SS, Martin CD (2010) Core disking and its relationship with stress magnitude for Lac du Bonnet granite. Int J Rock Mech Min Sci 47:254-264

Lin W, Yeh C-H, Hung J-H, Haimson B, Hirono T (2010) Localized rotation of principal stress around faults and fractures determined from borehole breakouts in hole B of the Taiwan Chelungpu-fault Drilling Project (TCDP). Tectonophysics 482:82-91 
Ljunggren C, Chang Y, Janson T, Christiansson R (2003) An overview of rock stress measurement methods. Int J Rock Mech Min Sci 40:975-989

Lund B, Zoback MD (1999) Orientation and magnitude of in situ stress to $6.5 \mathrm{~km}$ depth in the Baltic Shield. Int J Rock Mech Min Sci 36:169-190

Martin CD, Chandler NA (1993) Stress heterogeneity and geological structures. Int J Rock Mech Min Sci Geomech Abstr 30:993-999

Matsuki K, Kaga N, Yokoyama T, Tsuda N (2004) Determination of the three-dimensional in situ stress from core discing based on the analysis of principal tensile stress. Int J Rock Mech Min Sci 41:1167-1190

Müller B, Zoback ML, Fuchs K, Mastin L, Gregersen S, Pavoni N, Stephansson O, Ljunggren C (1992) Regional patterns of tectonic stress in Europe. J Geophys Res 97:11783-11803

Myrvang A (1993) Rock stress and rock stress problem in Norway. In: Hudson JA (ed) Comprehensive rock engineering, vol 3, Pergamon Press, Oxford, pp 461-471

Obara Y, Ishiguro Y (2004) Measurements of induced stress and strength in the near-field around a tunnel and associated estimation of the Mohr-Coulomb parameters for rock mass strength. Int J Rock Mech Min Sci 41:761-769

Roth F, Fleckenstein P (2001) Stress orientations found in North-East Germany differ from the West European trend. Terra Nova 13:289-296

Scotti O, Cornet FH (1994) In situ stress fields and focal mechanism solutions in central France. Geophys Res Lett 21:2345-2348

Shen B (2008) Borehole breakouts and in situ stresses. In: Potvin Y, Carter J, Dyskin A, Jeffrey J (eds) SHIRMS 2008. Australian Centre for Geomechanics, Perth, pp 407-418

Sjöberg J, Christiansson R, Hudson JA (2003) ISRM suggested methods for rock stress estimation-Part 2: overcoring methods. Int J Rock Mech Min Sci 40:999-1010

SKB (2008) Site description of Forsmark at completion of the site investigation phase. SDM-Site Forsmark. Swedish Nuclear Fuel and Waste Management Co, SKB Technical Report, TR-08-05 (downloadable from http://www.skb.se), Stockholm

Stephansson O (1983) Rock stress measurement by sleeve fracturing. In: Proceedings of 5th ISRM Congress, Melbourne. Balkema, Rotterdam, pp F129-F137

Stephansson O (1993) Rock stress in the Fennoscandian shield. In: Hudson JA (ed) Comprehensive rock engineering, vol 3, Pergamon Press, Oxford, pp 445-459
Stephansson O, Ljunggren C, Jing L (1991) Stress measurements and tectonic implications for Fennoscandia. Tectonophysics 189:317-322

Sturgul JR, Scheidegger AE, Greenspan Z (1976) Finite element model of a mountain massif. Geology 4:439-442

Su S, Stephansson O (1999) Effect of a fault on in situ stresses studied by the distinct element model. Int $\mathrm{J}$ Rock Mech Min Sci 36:1051-1056

Sugawara K, Obara Y (1995) Rock stress and rock stress measurements in Japan. In: Matsuki K, Sugawara K (eds) Proceedings of international workshop on rock stress measurement at Great Depth, Tokyo, Japan, 8th ISRM Congress. Balkema, Rotterdam, pp $1-8$

Tarantola A, Valette V (1982) Generalized non-linear inverse problem solved using the least squares criterion. Rev Geophys Space Phys 20:219-232

te Kamp L, Konietzky H, Blüming P (1999) Three-dimensional modelling of the planned Wellenberg repository site in Switzerland. In: Editors missing. Numerical methods in geomechanicsNUMOG VII. Balkema, Rotterdam, pp 385-390

Tonon F, Amadei B (2003) Stresses in anisotropic rock masses: an engineering perspective building on geological knowledge. Int $\mathrm{J}$ Rock Mech Min Sci 40:1099-1120

Wileveau Y, Cornet FH, Desroches J, Blümling P (2007) Complete in situ stress determination in the argillite sedimentary formation. Phys Chem Earth 32:866-878

Yale DP (2003) Fault and stress magnitude controls on the variations in the orientation of in situ stress. In: Ameen (ed) Fracture and in situ stress characterization of hydrocarbon reservoirs. Geological Society London, Special Publications 209, pp 55-64

Yin FM, Cornet FH (1994) Integrated stress determination by joint inversion of hydraulic tests and focal mechanisms. Geophys Res Lett 21:2645-2648

Zang A, Stephansson O (2010) Stress field of the Earth's crust. Springer Science and Business Media BV, Dordrecht

Zoback ML, Zoback MD, Adams J, Assumpcao M, Bell S, Bergman EA, Blümling P, Brereton NR, Denham D, Ding J, Fuchs K, Gay N, Gregersen S, Gupta HK, Gvishiani A, Jacob K, Klein R, Knoll P, Magee M, Mercier JL, Mueller BC, Paquin C, Rajendran K, Stephansson O, Suarez G, Suter M, Udias A, Xu ZH, Zhizhin M (1989) Global patterns of tectonic stress. Nature 341:291-298 